\title{
Atypical subependymal giant cell astrocytoma and neonatal tuberous sclerosis
}

Laiz Laura de Godoy, MD, and César Augusto Pinheiro Ferreira Alves, MD

Neurology ${ }^{\circledR}$ 2018;90:570-571. doi:10.1212/WNL.0000000000005181
Correspondence

Dr. de Godoy

laizgodoy@hotmail.com

Figure 1 Brain MRI

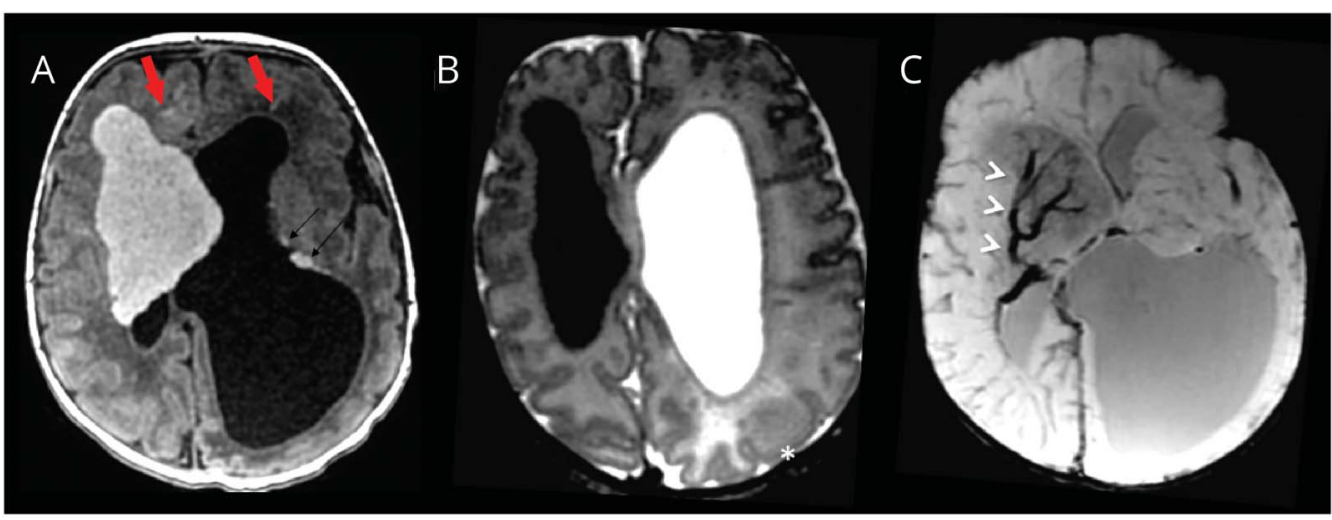

Axial MRI of tuberous sclerosis brain findings. Subependymal giant astrocytoma: (A) T1-hyperintese; (B) T2-hypointense; (C) susceptibility-weighted imaging-exuberant venous drainage (arrowheads). Subependymal nodules: (A) T1-hyperintese (black arrows), radial bands (red arrows); and (B) cortical tubers (asterisk).

A 9-day-old girl had, on prenatal ultrasound, brain and cardiac lesions suspicious for tuberous sclerosis. Brain MRI demonstrated a large intraventricular and intraparenchymal mass centered on the foramen of Monro, which had unusual imaging findings: a homogeneous T1hyperintense and T2-hypointense signal (figure 1, A and B) related to scarce myelination; remarkable venous drainage on susceptibility-weighted imaging (figure 1C); and apparent diffusion coefficient hypointensity, corresponding to blackout T2 effect (figure 2, A and B).

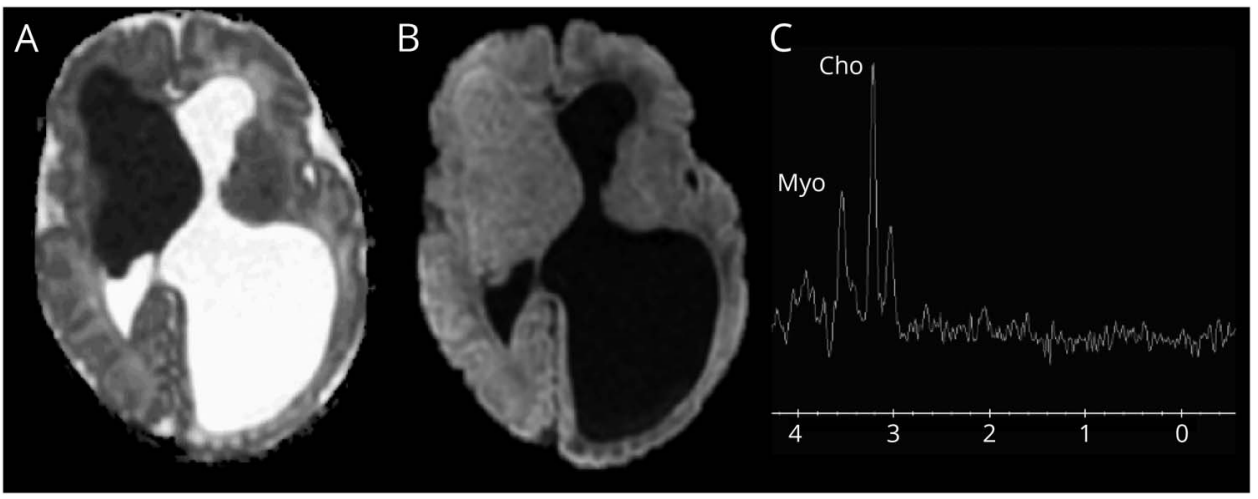

Subependymal giant astrocytoma: (A) apparent diffusion coefficient hypointense; (B) diffusion-weighted imaging isointense related to blackout T2 effect; (C) spectroscopy (point resolved spectroscopy echo time 35 ) study shows choline (Cho) $3.2 \mathrm{ppm}$ and myo-Inositol (Myo) $3.5 \mathrm{ppm}$ peaks. 
Spectroscopy showed increased choline and myo-Inositol peaks (figure $2 \mathrm{C}$ ). These findings are consistent with neonatal subependymal giant astrocytoma. ${ }^{1,2}$ Subependymal nodules, cortical tubers, and radial bands were also atypically $\mathrm{T} 1$ hyperintense and T2-hypointense (figure 1, A and B).

\section{Author contributions}

Laiz Laura de Godoy: study concept and design. César Augusto Pinheiro Ferreira Alves: study concept and design, critical revision of manuscript for intellectual content.

\section{Study funding}

No targeted funding reported.

\section{Disclosure}

The authors report no disclosures relevant to the manuscript. Go to Neurology.org/N for full disclosures.

\section{References}

1. Raju GP, Urion DK, Sahin M. Neonatal subependymal giant cell astrocytoma: new case and review of literature. Pediatr Neurol 2007;36:128-131.

2. Baron $\mathrm{Y}$, Barkovich AJ. MR imaging of tuberous sclerosis in neonates and young infants. AJNR Am J Neuroradiol 1999;20:907-916.

\section{Disputes \& Debates: Rapid online correspondence}

The editors encourage comments on recent articles through Disputes \& Debates:

Access an article at Neurology.org/ $N$ and click on "COMMENT" beneath the article header. Responses will be posted within 3 business days.

Before submitting a comment to Disputes \& Debates, remember the following:

- Disputes \& Debates is restricted to comments about studies published in Neurology within the last eight weeks

- Read previously posted comments; redundant comments will not be posted

- Your submission must be 200 words or less and have a maximum of five references; reference one must be the article on which you are commenting

- You can include a maximum of five authors (including yourself)

\section{The AAN is Fighting for You!}

In the midst of rapid changes in health care policy, the AAN has your back. From actively lobbying members of Congress to meeting with regulators to underscore the value of neurology and your services to your patients, the Academy is forcefully countering any threats to your profession and patient access to care. Learn more at AAN.com/policy-and-guidelines/advocacy, read the bimonthly Capitol Hill Report and monthly AANnews member magazine, and respond to Advocacy Action Alert emails when we invite you to share your voice with Congress. 


\section{Neurology}

\section{Atypical subependymal giant cell astrocytoma and neonatal tuberous sclerosis}

Laiz Laura de Godoy and César Augusto Pinheiro Ferreira Alves

Neurology 2018;90;570-571

DOI 10.1212/WNL.0000000000005181

This information is current as of March 19, 2018

Updated Information \& Services

References

Subspecialty Collections

Permissions \& Licensing

Reprints including high resolution figures, can be found at: http://n.neurology.org/content/90/12/570.full

This article cites 2 articles, 1 of which you can access for free at: http://n.neurology.org/content/90/12/570.full\#ref-list-1

This article, along with others on similar topics, appears in the following collection(s):

DWI

http://n.neurology.org/cgi/collection/dwi

MRI

http://n.neurology.org/cgi/collection/mri

Neonatal

http://n.neurology.org/cgi/collection/neonatal

Other neurocutaneous disorders

http://n.neurology.org/cgi/collection/other_neurocutaneous_disorders

Information about reproducing this article in parts (figures,tables) or in its entirety can be found online at:

http://www.neurology.org/about/about_the_journal\#permissions

Information about ordering reprints can be found online:

http://n.neurology.org/subscribers/advertise

Neurology ${ }^{\circledR}$ is the official journal of the American Academy of Neurology. Published continuously since 1951 , it is now a weekly with 48 issues per year. Copyright @ 2018 American Academy of Neurology. All rights reserved. Print ISSN: 0028-3878. Online ISSN: 1526-632X.

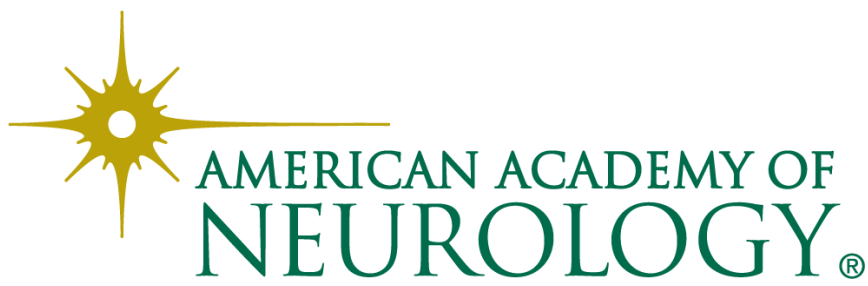

